\title{
Cytosolic $\mathrm{Cl}^{-}$Affects the Anticancer Activity of Paclitaxel in the Gastric Cancer Cell Line, MKN28 Cell
}

\author{
Sachie Tanaka ${ }^{a, c}$ Hiroaki Miyazakia Atsushi Shiozakic Daisuke Ichikawa ${ }^{c}$ \\ Eigo Otsujic Yoshinori Marunaka, ${ }^{a, b}$ \\ aDepartment of Molecular Cell Physiology, Kyoto Prefectural University of Medicine, Kyoto, \\ ${ }^{b}$ Department of Bio-Ionomics, Kyoto Prefectural University of Medicine, Kyoto, 'Division of Digestive \\ Surgery, Department of Surgery, Kyoto Prefectural University of Medicine, Kyoto, Japan
}

\section{Key Words}

Cytosolic chloride $\bullet$ Paclitaxel $•$ Cell proliferation $\bullet$ Microtubule polymerization $•$ Gastric cancer

\begin{abstract}
Background/Aims: Our previous study revealed that cytosolic $\mathrm{Cl}^{-}$affected neurite elongation promoted via assembly of microtubule in rat pheochromocytoma PC12D cells and $\mathrm{Cl}^{-}$-induced blockade of intrinsic GTPase enhanced tubulin polymerization in vitro. Paclitaxel (PTX) is a microtubule-targeted chemotherapeutic drug and stabilizes microtubules resulting in mainly blockade of mitosis at the metaphase-anaphase transition and induction of apoptosis. In the present study, we tried to clarify whether the cytosolic $\mathrm{Cl}^{-}$affected PTX ability to inhibit cell growth in the gastric cancer cell line, MKN28. Methods: To clarify the cytosolic $\mathrm{Cl}^{-}$action on PTX-induced cell death and metaphase-anaphase transition in the gastric cancer cell line, MKN28 cell, and PTX-induced tubulin polymerization, we performed cell proliferation assay, cytosolic $\mathrm{Cl}^{-}$concentration measurement, immunofluorescence microscopy, and in vitro tubulin polymerization assay. Results: The decline of cytosolic $\mathrm{Cl}^{-}$weakened the cytotoxic effect of PTX on cell proliferation of MKN28 cells, which could pass through the metaphase-anaphase transition. Moreover, in vitro PTX-induced tubulin polymerization was diminished under the low $\mathrm{Cl}^{-}$condition. Conclusions: Our results strongly suggest that the upregulation of cytosolic $\mathrm{Cl}^{-}$concentration would enhance the antitumor effect of PTX, and that the cytosolic $\mathrm{Cl}^{-}$would be one of the key targets for anti-cancer therapy.
\end{abstract}

(C) 2017 The Author(s)

Published by S. Karger AG, Basel

\section{Introduction}

Microtubules are one of major cytoskeletal structures composed of $\alpha$ - and $\beta$-tubulin heterodimers that form hollow fibers and show highly dynamic movements [1, 2]. They are involved in various cellular functions such as chromosome segregation, intracellular vesicle $\mathrm{S}$. Tanaka and H. Miyazaki contributed equally to the present study.

Hiroaki Miyazaki, Ph.D. and

Yoshinori Marunaka, M.D., Ph.D.

KARGER
Department of Molecular Cell Physiology, Kyoto Prefectural University of Medicine, Kyoto 602-8566, (Japan)

Tel.+81-75-251-5311, E-Mail hmiyazak@koto.kpu-m.ac.jp / marunaka@koto.kpu-m.ac.jp 


\section{Cellular Physiology Cell Physiol Biochem 2017;42:68-80 \begin{tabular}{l|l} 
DOI: 10.1159/000477116 & O 2017 The Author(s). Published by S. Karger AG, Basel \\
www.karger.com/cpb
\end{tabular} \\ Tanaka et al.: Effect of Cytosolic $\mathrm{Cl}^{-}$on the Anticancer Activity of Paclitaxel}

transport, cell polarity and cell motility. Microtubule dynamics as well as associated signaling pathways are important targets for novel anti-cancer therapies [3]. Therefore, microtubule targeting agents have become a very successful class of cancer drugs that have established their potency and efficiency against many cancer types. Paclitaxel (PTX) is a clinically successful microtubule-targeted chemotherapeutic drug binding $\beta$-tubulin and stabilizes microtubules resulting in mainly blockade of mitosis at metaphase-anaphase transition and induction of apoptosis [3-5].

Recent studies have revealed that ion channels and transporters play important roles in fundamental cellular functions. Among them, several reports have shown that $\mathrm{Cl}^{-}$channels might regulate various cellular functions such as cell cycle progression, proliferation, adhesion and migration including cancer cells [6-10]. We have previously reported that reduction of cytosolic $\mathrm{Cl}^{-}$concentration enhance gene expression of the $\alpha$-subunit of epithelial $\mathrm{Na}^{+}$channel in Xenopus laevis kidney A6 cells [11]. Moreover, our previous studies have shown that MKN28 cells, a human gastric cancer cell line, cultured in a low $\mathrm{Cl}^{-}$medium exhibit a decrease in cytosolic $\mathrm{Cl}^{-}$concentration and reduced proliferation with the G0/G1 phase arrest, which is accompanied with activation of p38 mitogen-activated protein kinase and c-Jun N-terminal kinase, and up-regulation of p21, an inhibitor of cyclin-dependent kinases (CDKs) $[12,13]$. We have also demonstrated that $\mathrm{Na}^{+}-\mathrm{K}^{+}-2 \mathrm{Cl}^{-}$-cotransporter (NKCC1) expression plays a fundamental role in NGF-induced neurite outgrowth of PC12D cells [14] and $\mathrm{Cl}^{-}$-induced blockade of intrinsic GTPase enhances tubulin polymerization in vitro [15]. Each tubulin subunit can bind to guanine nucleotides; one exchangeable ( $\beta$-subunit binding) and the other unexchangeable ( $\alpha$-subunit binding) [16]. Only a GTP-bound form of tubulin can be assembled to tubulin forming microtubule, while tubulin has an intrinsic GTPase activity contributing to disassembly of polymerized tubulin via hydrolysis of GTP bound to tubulin [16]. Therefore, these observations suggest that GTPase activity of tubulin polymers is one of key factors regulating polymerization of tubulin and that the cytosolic $\mathrm{Cl}^{-}$would also be an important factor for regulating the microtubule dynamics.

In the present study, we tried to clarify whether the cytosolic $\mathrm{Cl}^{-}$affected PTX-induced cell death in the gastric cancer cell line, MKN28. We demonstrated that the decline of $\mathrm{Cl}^{-}$ concentration weakened the cytotoxic effects of PTX in MKN28 cells and inhibited PTXinduced in vitro tubulin polymerization. These results strongly suggest that the upregulation of cytosolic $\mathrm{Cl}^{-}$concentration would enhance the antitumor effect of PTX, and that the cytosolic $\mathrm{Cl}^{-}$would be one of the key targets for anti-cancer therapy.

\section{Materials and Methods}

\section{Cell culture}

Human gastric adenocarcinoma MKN28 cells were cultured with RPMI 1640 (Sigma-Aldrich, St. Louis, MO, USA) (normal $\mathrm{Cl}^{-}$medium) containing 5\% fetal bovine serum (FBS) in a humidified incubator at $37^{\circ} \mathrm{C}$ with $5 \% \mathrm{CO}_{2}$ in air. To perform various experiments with MKN28 cells under a low chloride condition, we used a $\mathrm{Cl}^{-}$-replaced RPMI medium (Cell Science and Technology Institute, Sendai, Japan) (low $\mathrm{Cl}^{-}$medium), which was prepared by substituting $\mathrm{Cl}^{-}$with $\mathrm{NO}_{3}$ - This medium was also supplemented with $5 \% \mathrm{FBS}$. Actual $\mathrm{Cl}^{-}$concentrations of culture media were measured by using QuantiChrom Chloride Assay Kit (BioAssay Systems, Hayward, CA, USA). The $\mathrm{Cl}^{-}$concentration of normal $\mathrm{Cl}^{-}$medium was $107.3 \pm 1.3 \mathrm{mM}(n=3)$. The actual $\mathrm{Cl}^{-}$concentration of low $\mathrm{Cl}^{-}$medium was $4.2 \pm 0.3 \mathrm{mM}(n=3)$. We mixed the low $\mathrm{Cl}^{-}$medium with the normal $\mathrm{Cl}^{-}$medium at various ratios to set the $\mathrm{Cl}^{-}$concentrations of media at various levels, and the actual $\mathrm{Cl}^{-}$ concentrations in the media were also measured with QuantiChrom Chloride Assay Kit and were described in Figure $1 \mathrm{~A}$ and $1 \mathrm{~B}$.

Cell proliferation assay in culture media containing various $\mathrm{Cl}$ concentration

Cells were seeded into 6 well plate at density of $5.0 \times 10^{4}$ cells/well and incubated for $24 \mathrm{~h}$ in the normal $\mathrm{Cl}^{-}$medium supplemented with $5 \%$ FBS. We defined this time point just after this $24 \mathrm{~h}$ incubation as time zero $(0 \mathrm{~h})$. Then, cells were cultured under various $\mathrm{Cl}^{-}$concentration levels. After culture under each 


\section{Cellular Physiology Cell Physiol Biochem 2017;42:68-80 and Biochemistry Published onlIne: May 12, $2017 \quad$\begin{tabular}{l|l} 
DOI: 10.1159/000477116 2017 The Author(s). Published by S. Karger AG, Basel \\
www.karger.com/cpb
\end{tabular} \\ Tanaka et al.: Effect of Cytosolic $\mathrm{Cl}^{-}$on the Anticancer Activity of Paclitaxel}

experimental condition for $72 \mathrm{~h}$, cells were detached from the wells in a trypsin-EDTA and counted on a hemocytometer.

Effect of paclitaxel treatment on cell proliferation

MKN28 cells were seeded into $25 \mathrm{~cm}^{2}$ flasks at density of $2.5 \times 10^{5}$ cells/flask and incubated for $24 \mathrm{~h}$ in the normal $\mathrm{Cl}^{-}$medium. We defined this time point just after this $24 \mathrm{~h}$-incubation as time zero $(0 \mathrm{~h})$. Then, cells were cultured in each $\mathrm{Cl}^{-}$concentration medium containing paclitaxel (PTX, Sigma-Aldrich) or dimethyl sulfoxide (DMSO, Sigma-Aldrich) as a solvent control for PTX. The final concentrations of PTX used in this study were 2.5, 5 and $10 \mathrm{nM}$, and the concentration of DMSO (0 nM PTX) was $0.1 \%$. After culturing under each experimental condition for $72 \mathrm{~h}$, cells were detached from flasks in a trypsin-EDTA and counted using a hemocytometer.

\section{Measurement of cytosolic $\mathrm{Cl}$ concentration}

MKN28 cells were seeded into $75 \mathrm{~cm}^{2}$ flasks at density of $7.5 \times 10^{5}$ cells/flask and incubated for $24 \mathrm{~h}$ in the normal $\mathrm{Cl}^{-}$medium supplemented with 5\% FBS, and we then applied the media containing various $\mathrm{Cl}^{-}$concentrations. At $72 \mathrm{~h}$ after the application, we measured cytosolic $\mathrm{Cl}^{-}$concentration with the same methods as we previously reported [12]. Cells were applied $5.0 \mathrm{mM} \mathrm{N}$-(ethoxycarbonylmethyl)-6methoxyquinolinium bromide (MQAE) (DOJINDO, Kumamoto, Japan), a halide-sensitive dye, for $24 \mathrm{~h}$ before analysis. The methods of MQAE-load and calibration of the fluorescence in terms of cytosolic $\mathrm{Cl}^{-}$ concentration were performed by the same method as previously reported [12].

Effect of paclitaxel treatment on cytosolic Cl concentration

MKN28 cells were seeded into $75 \mathrm{~cm}^{2}$ flasks at density of $7.5 \times 10^{5}$ cells/flask and incubated for 24 $\mathrm{h}$ in the normal $\mathrm{Cl}^{-}$medium. Then, cells were cultured in each $\mathrm{Cl}^{-}$concentration medium containing PTX (Sigma-Aldrich) or DMSO (Sigma-Aldrich) as a solvent control for PTX. The final concentration of PTX used in this study was $5 \mathrm{nM}$, and the concentration of DMSO ( $0 \mathrm{nM} \mathrm{PTX)} \mathrm{was} 0.1 \%$. At $72 \mathrm{~h}$ after the application of each medium, cytosolic $\mathrm{Cl}^{-}$concentration was determined with the same method as we previously reported [12]. $5.0 \mathrm{mM}$ MQAE (DOJINDO) of $5.0 \mathrm{mM}$ was applied to cells for $24 \mathrm{~h}$ before measurement in each $\mathrm{Cl}^{-}$ concentration medium containing $5 \mathrm{nM}$ PTX or $0.1 \%$ DMSO as a solvent control.

Synchronization of cell cycle phase to the mitotic period and cell cycle analysis

The cell cycle of MKN28 cells was synchronized by the double thymidine block method [17, 18]. Briefly, MKN28 cells were seeded into $25 \mathrm{~cm}^{2}$ flasks at density of $3.0 \times 10^{5}$ cells/flask and incubated for $12 \mathrm{~h}$ in the normal $\mathrm{Cl}^{-}$medium. The cells were cultured in the medium containing $3 \mathrm{mM}$ thymidine for $12 \mathrm{~h}$, then the thymidine was removed and cells were cultured with the normal Cl- medium for next $12 \mathrm{~h}$. Thereafter, cells were exposed to second thymidine for $12 \mathrm{~h}$. The cell cycle was synchronized at the G1 to $\mathrm{S}$ phase border by this treatment. Then, the cells were washed with the normal $\mathrm{Cl}^{-}$medium to remove thymidine, and allowed to proliferate in the fresh normal $\mathrm{Cl}^{-}$medium. After culturing in the normal $\mathrm{Cl}^{-}$medium for $7 \mathrm{~h}$, it might be the time just before mitotic period, culture media were replaced with each $\mathrm{Cl}^{-}$concentration medium containing $10 \mathrm{nM}$ PTX. We defined this time point as time zero $(0 \mathrm{~h})$. At every $2 \mathrm{~h}$ (from 2 to $16 \mathrm{~h}$ ), the cells were detached from the flasks by trypsin-EDTA treatment and prepared for flow cytometry. A nuclear isolation medium (NIM-DAPI 10, Beckman Coulter, Fullerton, CA, USA) was added to the cell pellets for staining cells. Ten thousand cells were examined by the Cell Lab Quanta (Beckman Coulter) with an excitation at $365 \mathrm{~nm}$ and emission at $450 \mathrm{~nm}$ for DAPI. Cell cycle phases were analyzed by using Flow Jo software (Tree Star Inc., Ashland, OR, USA).

Immunofluorescence staining for tubulin at the mitotic phase of the cell cycle

MKN28 cells were seeded on glass cover slides in 12 well plate at density of $1.0 \times 10^{5}$ cells/well and cultured for $12 \mathrm{~h}$ in the normal $\mathrm{Cl}^{-}$medium. For cell cycle synchronization in $\mathrm{M}$ phase, cells were treated with $5 \mu$ M R0-3306 (Sigma-Aldrich), a Cdk1-inhibitor, in the normal Cl- medium for $21 \mathrm{~h}$ to arrest cells at the G2/M border [19, 20]. Subsequently, RO-3306 containing media were removed and cells were cultured in normal $\mathrm{Cl}^{\circ}$ or low $\mathrm{Cl}^{-}$media with $10 \mathrm{nM}$ PTX. We defined this time point just after this $21 \mathrm{~h}$-incubation as time zero (0 min). At $0,15,30,45,60,75,90$ and $105 \mathrm{~min}$, cells were fixed in PTEMF buffer $(20 \mathrm{mM}$ PIPES (pH 6.9), 0.2\% Triton X-100, $10 \mathrm{mM}$ EGTA, $1 \mathrm{mM} \mathrm{MgCl} 2,4 \%$ paraformaldehyde) for $30 \mathrm{~min}$ at room 


\section{Cellular Physiology Cell Physiol Biochem 2017;42:68-80 \begin{tabular}{l|l} 
DOI: 10.1159/000477116 & O 2017 The Author(s). Published by S. Karger AG, Basel \\
www.karger.com/cpb
\end{tabular} \\ Tanaka et al.: Effect of Cytosolic $\mathrm{Cl}^{-}$on the Anticancer Activity of Paclitaxel}

temperature $[19,20]$. Fixed cells were permeabilized and blocked in $0.1 \%$ saponin and $3 \%$ bovine serum albumin with PBS for $1 \mathrm{~h}$ and then sequentially incubated with a primary antibody (anti- $\alpha$ tubulin antibody, 1:200, Bio-Rad, Hercules, CA, USA) and a secondary antibody (AlexaFluor 488 anti-donkey IgG, 1:1000, Thermo Fisher Scientific) for $1 \mathrm{~h}$ each. Then, cells were mounted with VECTASHIELD Mounting Medium Hard Set with DAPI (Vector Laboratories, Burlingame, CA, USA). Finally, cells were analyzed using the LSM 510 Meta confocal microscope and ZEN 2012 software (Carl Zeiss, Oberkochen, Germany). At least 2400 cells from four independent experiments were counted to determine the ratio of each mitotic phase.

In vitro tubulin polymerization assay

The in vitro polymerization of purified porcine brain tubulin (Cytoskeleton Inc., Denver, CO, USA) was evaluated by spectrophotometry according to the original method of Gaskin and Cantor [21]. Briefly, tubulin stocks $(10 \mathrm{mg} / \mathrm{ml})$ were prepared by reconstituting purified porcine tubulin in a tubulin stock buffers (80 mM PIPES, $50 \mathrm{mM} \mathrm{KCl,} 2 \mathrm{mM} \mathrm{MgCl}$, $1 \mathrm{mM} \mathrm{GTP}$ or GTP $\gamma \mathrm{S}$ (non-hydrolyzable analog of GTP) [22, 23], and 0.5 mM EGTA, pH 6.9 with $\mathrm{KOH}$ ). Thereafter, tubulin stocks were diluted with normal $\mathrm{Cl}^{-}$glycerol buffer (40 mM PIPES, $50 \mathrm{mM} \mathrm{KCl,} 2 \mathrm{mM} \mathrm{MgCl}_{2}$, 5.6\% Glycerol and $1 \mathrm{mM} \mathrm{GTP} \mathrm{or} \mathrm{GTP} \gamma \mathrm{S}$ ) or low $\mathrm{Cl}^{-}$glycerol buffer (40 mM PIPES, $50 \mathrm{mM} \mathrm{KNO}_{3}, 2 \mathrm{mM} \mathrm{Mg}\left(\mathrm{NO}_{3}\right)_{2}, 1 \mathrm{mM} \mathrm{GTP}$ or GTP $\gamma$, and 5.6\% Glycerol) at various ratio to set final $\mathrm{Cl}^{-}$concentration were 5, 30, 45 and $50 \mathrm{mM}$ with $10 \mu \mathrm{M}$ PTX. The final concentration of tubulin was $1 \mathrm{mg} /$ $\mathrm{ml}$, at the concentration of which tubulin was not polymerized without PTX. Tubulin polymerization was started by incubation with PTX at $37^{\circ} \mathrm{C}$ and evaluated by absorption readings at $340 \mathrm{~nm}$ using a plate reader, SpectraMax M2e (Molecular Devices, LLC., Sunnyvale, CA, USA), over 1 min-interval for 30 min.

\section{Statistical analysis}

Data are expressed as means \pm SEM. Differences were analyzed by pared $t$-test, and were considered significant when the p-value was less than 0.05 .

\section{Results}

Cell proliferation of MKN28 cells was affected by $\mathrm{Cl}$ concentration in culture media

The cytosolic $\mathrm{Cl}^{-}$concentration of MKN28 cells incubated in the normal $\mathrm{Cl}^{-}(107.3$ $\mathrm{mM})$ medium was $51.7 \pm 2.7 \mathrm{mM}(n=8)$. When MKN28 cells were incubated in the low $\mathrm{Cl}^{-}$medium (4.2 mM) for $72 \mathrm{~h}$, the cytosolic $\mathrm{Cl}^{-}$concentration diminished to around $\sim 8 \mathrm{mM}$ $(7.8 \pm 3.1 \mathrm{mM} ; n=5)$. Further, the cytosolic $\mathrm{Cl}^{-}$concentration of MKN28 cells cultured in the media containing various $\mathrm{Cl}^{-}$concentrations was proportionally dependent on the chloride concentration of the cultured medium (Fig. 1A). Figure 1B shows the relative cell numbers of MKN28 cells at $72 \mathrm{~h}$ after the culture in the media containing various $\mathrm{Cl}^{-}$concentrations $(4.2,29.4,55.0,82.4$, and $107.3 \mathrm{mM})$. The rate of cell proliferation was dependent on the extracellular $\mathrm{Cl}^{-}$concentration similar to our observations previously reported [12].

\section{A}

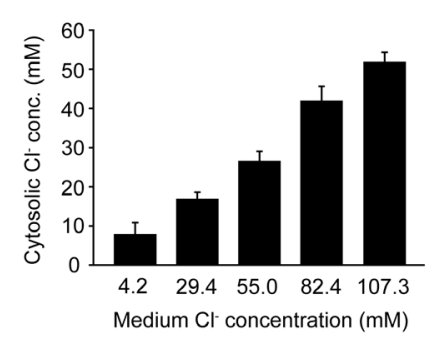

B

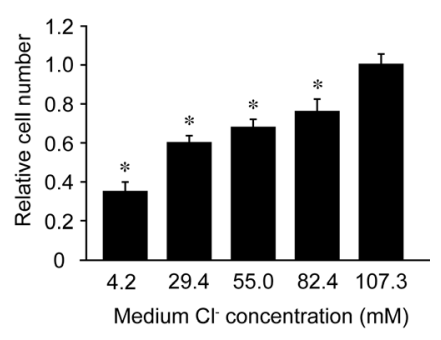

Fig. 1. (A) Cytosolic $\mathrm{Cl}^{-}$concentration of MKN28 cells cultured in the media containing various chloride concentrations for 72 h. $n=4$ - 8. (B) Relative cell number of MKN28 cells at $72 \mathrm{~h}$ after the cells were cultured in the media containing various chloride concentrations. The data shown here were normalized to the value of that in the normal $\mathrm{Cl}^{-}(107.3 \mathrm{mM})$ medium. ${ }^{*} p<0.05$ compared with those in the normal $\mathrm{Cl}^{-}$medium $(107.3$ $\mathrm{mM}) \cdot n=4$.

\section{KARGER}


Fig. 2. Effect of paclitaxel (PTX) on cell proliferation and cytosolic $\mathrm{Cl}^{-}$ concentration of MKN28 cells in normal $\mathrm{Cl}^{-}(107.3$ $\mathrm{mM})$ or low $\mathrm{Cl}^{-}(4.2 \mathrm{mM})$ media. Cell number at 72 $\mathrm{h}$ (A) in normal $\mathrm{Cl}^{-}$or (B) low $\mathrm{Cl}^{-}$media with PTX of various concentrations $(0$, 2.5, 5.0 and $10 \mathrm{nM}$ ). ${ }^{*} p<$ 0.05 compared with those in $0 \mathrm{nM}$ PTX containing media. $n=4$. (C) Relative cell number at $72 \mathrm{~h}$ normalized to the value of $0 \mathrm{nM}$ PTX in each condition. ${ }^{*} p<$ 0.05 compared with those in the normal $\mathrm{Cl}^{-}$medium with each concentration of PTX. $n=4$. (D) Cytosolic $\mathrm{Cl}^{-}$

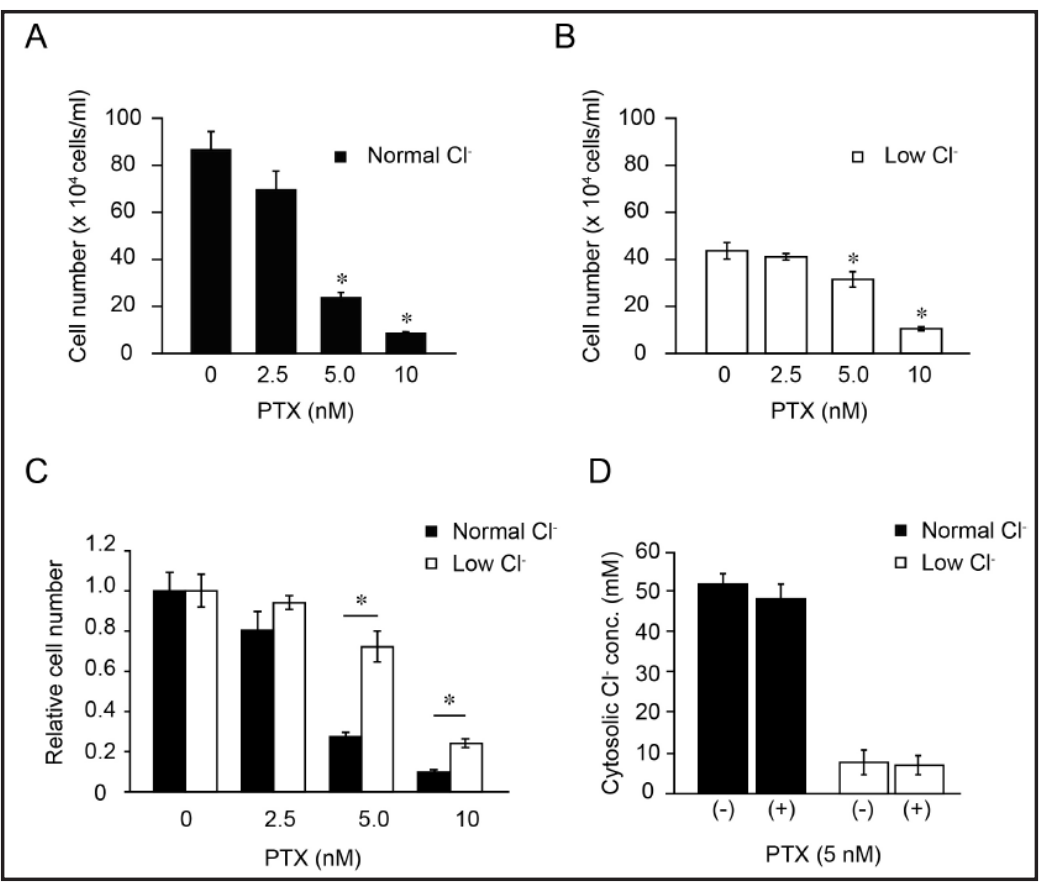
concentration of MKN28 cells cultured in normal $\mathrm{Cl}^{-}$or low $\mathrm{Cl}^{-}$media containing with or without $5 \mathrm{nM}$ PTX for 72 h. $n=4-8$.

The inhibitory effects of PTX on cell proliferation were attenuated under low $\mathrm{Cl}$ conditions in MKN28 cells

To assess the effect of $\mathrm{Cl}^{-}$on antitumor activity of PTX, we first measured cell proliferation of MKN28 cells in normal $\mathrm{Cl}^{-}(107.3 \mathrm{mM})$ or low $\mathrm{Cl}^{-}(4.2 \mathrm{mM})$ media with PTX of various concentrations $(0,2.5,5.0$ and $10 \mathrm{nM})$. In both $\mathrm{Cl}^{-}$conditions, the cell growth of MKN28 cells was diminished in proportion to the PTX concentration in each buffer (Fig. 2A and 2B), however, the inhibitory effects of PTX on cell proliferation were highly dependent on $\mathrm{Cl}^{-}$ concentration in culture media. Figure $2 \mathrm{C}$ shows the relative cell numbers of MKN28 cells at $72 \mathrm{~h}$ after application of normal $\mathrm{Cl}^{-}$or low $\mathrm{Cl}^{-}$culture media. The data were normalized to the cell number in each $\mathrm{Cl}^{-}$concentration media without PTX $(0 \mathrm{nM})$. In the normal $\mathrm{Cl}^{-}$medium, only about $30 \%$ and $10 \%$ cells respectively survived after treatment with 5 and $10 \mathrm{nM}$ PTX for $72 \mathrm{~h}$, while cell viability was markedly rescued (about $70 \%$ and $25 \%$ cells survived after treatment with 5 and $10 \mathrm{nM}$ PTX, respectively) by culturing in the low $\mathrm{Cl}^{-}$medium at all tested PTX concentrations (Fig. 2C). Figure 2D shows the cytosolic $\mathrm{Cl}^{-}$concentrations in MKN28 cells treated with or without $5 \mathrm{nM}$ PTX. There were no significant differences in cytosolic $\mathrm{Cl}^{-}$concentrations between cells cultured in the medium containing with or without PTX. Accordingly, these data suggest that the diminution of cytosolic $\mathrm{Cl}^{-}$concentration would attenuate the antiproliferative effect of PTX.

The diminution of cytosolic $\mathrm{Cl}$ concentration attenuated PTX-induced inhibition of M to G1 phase transition of the cell cycle in MKN28 cells

It is well known that PTX can suppress cell growth through blocking the M to G1 phase cell cycle transition. We therefore tried to analyze the effect of the cytosolic $\mathrm{Cl}^{-}$on PTXinduced delay of cell cycle progression in M to G1 phase by using cell cycle synchronization technique. MKN28 cells were synchronized at G1-S phase using the thymidine double block method. At $7 \mathrm{~h}$ after release from G1-S phase arrest, cells progressed just before G2 phase (data not shown), culture media were changed to normal $\mathrm{Cl}^{-}$or low $\mathrm{Cl}^{-}$media containing $10 \mathrm{nM}$ PTX. We defined this time point as time zero $(0 \mathrm{~h})$. Figure 3 shows representative histograms of DNA contents of MKN28 cells (A) and cell numbers in each cell cycle phase 


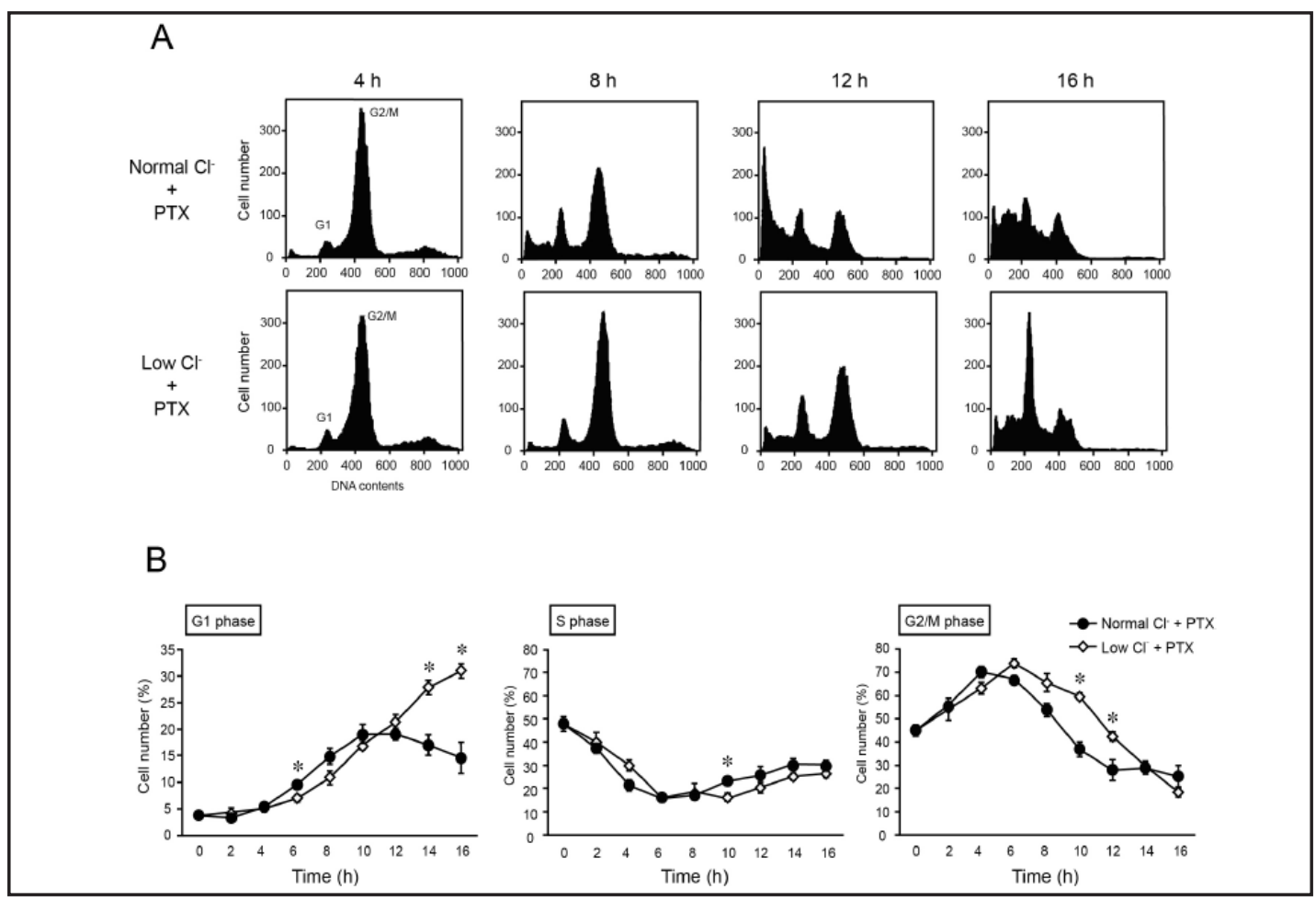

Fig. 3. Effect of $10 \mathrm{nM} P T X$ on cell cycle progression of MKN28 cells in normal $\mathrm{Cl}^{-}(107.3 \mathrm{mM})$ or low $\mathrm{Cl}^{-}(4.2$ $\mathrm{mM}$ ) media. The cell cycle of MKN28 cells was synchronized in G1 phase by the double thymidine block method. After culturing in the normal $\mathrm{Cl}^{-}$medium for $7 \mathrm{~h}$, the cells were cultured in each $\mathrm{Cl}^{-}$concentration medium containing $10 \mathrm{nM}$ PTX. We defined this time point as time zero (0 h). (A) Representative histograms of DNA contents in each $\mathrm{Cl}^{-}$condition. (B) The cell populations in each cell cycle phase (G1, S and G2/M phase) are shown at each time point in each $\mathrm{Cl}^{-}$condition. ${ }^{*} p<0.05$ compared with those in the normal $\mathrm{Cl}^{-}$medium containing PTX. $n=4$.

(the G1, S and G2/M phases) (B) at each time point after applying normal $\mathrm{Cl}^{-}$or low $\mathrm{Cl}^{-}$ media with $10 \mathrm{nM}$ PTX. The number of G1 phase cells gradually declined in the normal $\mathrm{Cl}^{-}$ condition but increased in the low $\mathrm{Cl}^{-}$condition with $10 \mathrm{nM}$ PTX condition from $12 \mathrm{~h}$ up to $16 \mathrm{~h}$ after medium change. This result demonstrated that PTX blocked mitotic transition and would induce apoptosis in the normal $\mathrm{Cl}^{-}$condition but the low $\mathrm{Cl}^{-}$condition weakened the blocking action of PTX on mitotic transition (G1 phase in Fig. 3B), although there were no major differences in the cell cycle progression in each cell cycle phase until $12 \mathrm{~h}$ after application of each $\mathrm{Cl}^{-}$concentration medium with PTX. These results revealed that, in the low $\mathrm{Cl}^{-}$condition, MKN28 cells could pass through mitotic phase even in the presence of PTX, which would block the cell cycle progression from M to G1 phase in the normal $\mathrm{Cl}^{-}$medium.

\section{Effects of PTX on mitotic entry and exit in MKN28 cells were influenced by changes in the} cytosolic $\mathrm{Cl}^{-}$concentration

It was known that PTX shows its ability to increase microtubule polymerization by binding to $\alpha$-tubulin resulted in reducing spindle microtubule dynamics and thus inhibiting the metaphase-anaphase transition. We performed further experiment to investigate the effect of cytosolic $\mathrm{Cl}^{-}$on each mitotic phase progression under PTX existence by immunofluorescence staining of $\alpha$-tubulin. MKN28 cells were synchronized at the G2/M border by using R0-3306, a cdk-1 inhibitor. Just after 21 h-incubation with RO-3306, culture media were changed to normal $\mathrm{Cl}^{-}$or low $\mathrm{Cl}^{-}$medium containing $10 \mathrm{nM}$ PTX. We defined this time point as time zero (0 min). Representative images of each mitotic phase (pro/prometaphase, metaphase, ana/telophase and cytokinesis) are shown in Figure 4A. Figures 4B and 4C demonstrate

\section{KARGER}


A

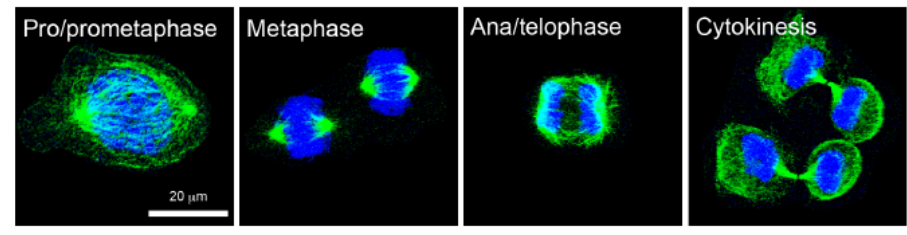

B

C
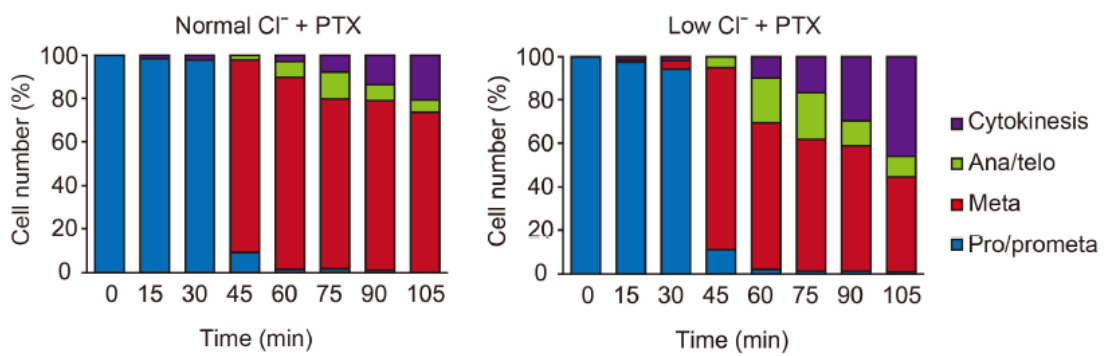

Fig. 4. Effect of $10 \mathrm{nM}$ PTX on mitotic progression of MKN28 cells in normal $\mathrm{Cl}^{-}(107.3 \mathrm{mM})$ or low $\mathrm{Cl}^{-}(4.2$ $\mathrm{mM}$ ) media analyzed by immunofluorescence staining of $\alpha$-tubulin. Cells were treated with $5 \mu \mathrm{M}$ RO-3306, and G2-arrested cells were cultured in normal $\mathrm{Cl}^{-}$or low $\mathrm{Cl}^{-}$media with $10 \mathrm{nM}$ PTX. Fixed cells were stained for $\alpha$-tubulin (green) and DNA (blue). (A) Representative images of each mitotic phase (pro/prometaphase, metaphase, ana/telophase and cytokinesis). (B) The ratio of cells at each mitotic phase during $M$ phase in normal $\mathrm{Cl}^{-}$or low $\mathrm{Cl}^{-}$media are shown. Bar, $20 \mu \mathrm{m} . n=4$.

Fig. 5. Effect of $\mathrm{Cl}^{-}$on $\mathrm{PTX}(10 \mu \mathrm{M})$-induced in vitro tubulin polymerization. (A) Tubulin polymerization was performed at $37^{\circ} \mathrm{C}$ for $15 \mathrm{~min}$ with various $\mathrm{Cl}^{-}$ concentration $(5,30,45$ and $50 \mathrm{mM})$ buffers containing $1 \mathrm{mM}$ GTP and determined by optical density (OD) at $340 \mathrm{~nm}$. Effect of non-hydrolyzable analogue of GTP (GTP $\gamma$ S) on PTX-induced in vitro tubulin polymerization. ${ }^{*} p<0.05$ compared with those in $50 \mathrm{mM}$ $\mathrm{Cl} . n=4$. (B) Relative OD values in $50 \mathrm{mM}$ or $5 \mathrm{mM}$ $\mathrm{Cl}^{-}$condition with $1 \mathrm{mM}$ GTP or GTP $\gamma$. The value of OD in $5 \mathrm{mM} \mathrm{Cl}^{-}$is normalized to that in $50 \mathrm{mM} \mathrm{Cl}^{-}$in each condition. ${ }^{*} p<0.05$ compared with those in 50 $\operatorname{mMCl}: n=4$.

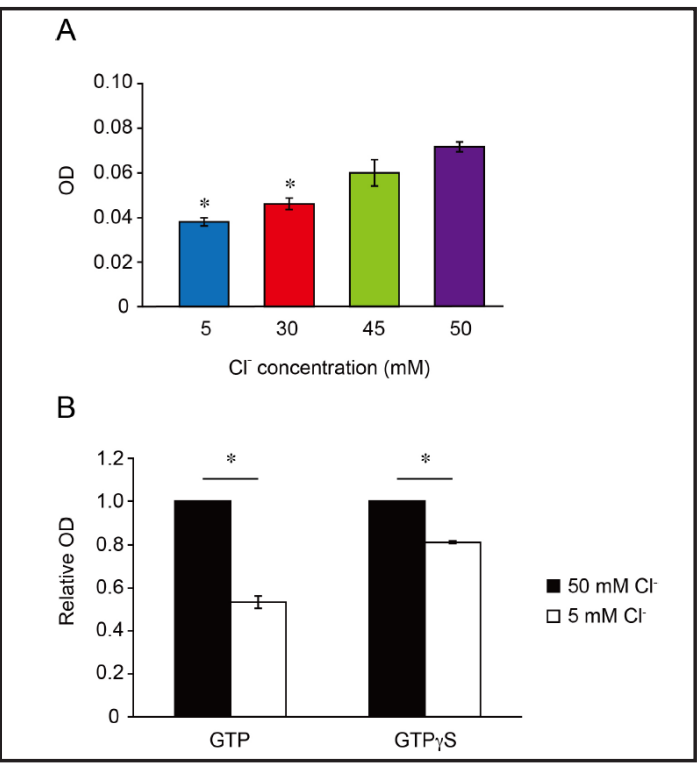

the proportion of cells in each phase during mitosis at $0,15,30,45,60,75,90$ and 105 min after changing culture media to normal $\mathrm{Cl}^{-}$or low $\mathrm{Cl}^{-}$media containing with PTX. At 45 min after releasing from G2/M arrest, a large number of cells stayed in mitotic metaphase, and there were no major differences in cell population of each mitotic phase under both $\mathrm{Cl}^{-}$ conditions. In the normal $\mathrm{Cl}^{-}$condition, although the cells in cytokinesis appeared at $60 \mathrm{~min}$ after changing culture media, the cells in metaphase accounted for a majority (about 70\%) of cells even at $105 \mathrm{~min}$, which means that PTX induced a mitotic arrest at metaphase (Fig. 4B). The cells in cytokinesis were also appeared at $60 \mathrm{~min}$ after changing culture media under the low $\mathrm{Cl}^{-}$condition, however, the cell population in cytokinesis was gradually increased, which was accompanied by decreasing that in metaphase, and the percentage of cells in cytokinesis reached about 45\% at 105 min (Fig. 4C). Namely, PTX blocked the metaphase- 
anaphase transition of MKN28 cells in the normal $\mathrm{Cl}^{-}$condition, whereas the inhibitory effect of PTX on mitosis was weakened in the low $\mathrm{Cl}^{-}$condition.

\section{Cl facilitated PTX-induced in vitro tubulin polymerization}

To determine the mechanism by which the decline of cytosolic $\mathrm{Cl}^{-}$concentration rescued PTX-induced inhibition of mitotic exit in MKN28 cells, we analyzed the effect of $\mathrm{Cl}^{-}$on the PTX-induced in vitro tubulin polymerization. Tubulin polymerization assay was performed in various $\mathrm{Cl}^{-}$concentration buffers containing with $10 \mu \mathrm{M}$ PTX at $37^{\circ} \mathrm{C}$ and evaluated by spectrophotometry at $340 \mathrm{~nm}$. Final concentration of tubulin was $1 \mathrm{mg} / \mathrm{ml}$, at the concentration of which tubulin was not polymerized without PTX (data not shown). Figure $5 \mathrm{~A}$ shows optical density (OD) at 15 min after starting tubulin polymerization in 5, 30, 45 and $50 \mathrm{mM} \mathrm{Cl}^{-}$reaction buffer and it was the time to reach a steady state of microtubule dynamics. It was found that the PTX-induced tubulin polymerization was increased in proportion to the $\mathrm{Cl}^{-}$concentration in reaction buffers (Fig. 5A). From these data, it was revealed that there was a linear correlation between the PTX-induced tubulin polymerization and $\mathrm{Cl}^{-}$concentration in reaction buffers. As we previously reported, $\mathrm{Cl}^{-}$partially inhibit GTPase activity of tubulin and have the enhanced effect of tubulin polymerization [15]. Therefore, we tested the effect of non-hydrolyzable GTP analogue $(\mathrm{GTP} \gamma \mathrm{S})$ on the PTX-induced tubulin polymerization in different $\mathrm{Cl}^{-}$concentration buffers. Figure 5B shows tubulin polymerization with GTP or GTP $\gamma \mathrm{S}$ in 5 or $50 \mathrm{mM} \mathrm{Cl}^{-}$buffer. The PTX-induced tubulin polymerization with GTP in $5 \mathrm{mM}$ $\mathrm{Cl}^{-}$was about $50 \%$ as compared to that in $50 \mathrm{mM} \mathrm{Cl}^{-}$. The inhibitory effect of low $\mathrm{Cl}^{-}$condition for tubulin polymerization was rescued by using GTP $\gamma$ S, although GTP $\gamma$ S could not completely rescue the low $\mathrm{Cl}^{-}$-induced inhibition in tubulin polymerization (tubulin polymerization in 5 $\mathrm{mM} \mathrm{Cl}^{-}$was about $80 \%$ as compared to that in $50 \mathrm{mM} \mathrm{Cl}^{-}$) (Fig 5B). These data suggest that PTX-induced tubulin polymerization was partially affected by changing the $\mathrm{Cl}^{-}$concentration via alteration in its intrinsic GTPase activity.

\section{Discussion}

Recent studies have revealed that $\mathrm{Cl}^{-}$plays fundamental roles in various cellular functions, such as cell cycle progression and proliferation [12, 13, 24-29], water secretion [30-32], regulation of gene expression [11,33,34], adhesion and migration of cells [6, 3537 , and neurite outgrowth in neuronal cells [14, 38-40]. Nakajima et al. [15] have also demonstrated that microtubule polymerization was enhanced by the presence of $\mathrm{Cl}^{-}$via inhibition of intrinsic GTPase activity of $\alpha$-tubulin in vitro. Paclitaxel (PTX) is a microtubuletargeted chemotherapeutic drug which binding to $\beta$-tubulin and stabilizes microtubules resulting in mainly blockade of mitosis at metaphase-anaphase transition and induction of apoptosis [3-5]. Therefore, it is supposed that $\mathrm{Cl}^{-}$will also affect the antitumor activity of PTX and we focused on the effect of $\mathrm{Cl}^{-}$on the antitumor activity of PTX.

In the present study, the metaphase-anaphase transition of MKN28 cells was blocked by the application of $10 \mathrm{nM}$ PTX in the normal $\mathrm{Cl}^{-}$condition. This concentration of PTX is far below that necessary to induce microtubule polymerization in vitro $(10 \mu \mathrm{M})$. Previous studies [41-43] have also revealed that cytotoxic concentration (about $4 \sim 8 \mathrm{nM}$ ) of PTX for paclitaxel-sensitive tumor cell lines are much lower than the effective concentration (about $0.5 \sim 4 \mu \mathrm{M}$ ) of PTX for promotion of tubulin polymerization. Jordan et al. [44] have demonstrated that PTX is concentrated several hundred fold intracellulary in HeLa cells. That is, after incubation of cells with $10 \mathrm{nM}$ PTX in the culture medium for $20 \mathrm{~h}$, PTX is concentrated 480 -fold to an intracellular level of $4.8 \mu \mathrm{M}$ [44]. Based on these results, it is likely that the overall intracellular PTX concentration is sufficient to stabilize tubulin polymerization and affect microtubule dynamics, even in MKN28 cells.

We also demonstrated that cell growth was certainly inhibited by the exposure of cells to the $\mathrm{Cl}^{-}$replaced medium (Fig. 1B) and that PTX dose-dependently inhibited cell growth of MKN28 gastric cancer cell both in normal $\mathrm{Cl}^{-}$or low $\mathrm{Cl}^{-}$medium (Fig. 2A and 2B). However, 
the relative antiproliferative effects of PTX on cell growth were obviously diminished in the low $\mathrm{Cl}^{-}$condition (Fig. 2C). Our previous study demonstrated that the decrease of cytosolic $\mathrm{Cl}^{-}$concentration specifically delayed the cell-cycle transition from G1 to S phase through a pathway dependent on p21, a CDK inhibitor, and induced G1 cell-cycle arrest [12,13]. On the other hands, the decrease of cytosolic $\mathrm{Cl}^{-}$concentration did not affect mitotic progression $[12,13]$, which was a key target of PTX $[3,45]$. Therefore, to elucidate the effect of $\mathrm{Cl}^{-}$on PTXinduced mitotic perturbations more directly, we synchronized cell cycle progression at the G1 to S phase and confirmed the limited effect of PTX on cell cycle transition from mitosis to G1 phase. In this study, we showed that MKN28 cells cultured with the low $\mathrm{Cl}^{-}$medium could go into G1 phase (Fig. 3A and 3B) and pass through the metaphase-anaphase transition (Fig. 4 ) in individual cells even in the presence of $10 \mathrm{nM}$ PTX. Namely, the antiproliferative activity of PTX for MKN28 cells markedly reduced under the low $\mathrm{Cl}^{-}$condition.

PTX increases the rate and extent of microtubule assembly in vitro, leading to stabilization of microtubules in vitro and in cells $[46,47]$. In the present work, we analyzed the effect of $\mathrm{Cl}^{-}$on the PTX-induced in vitro tubulin polymerization and demonstrated that the PTX-induced tubulin polymerization was increased in proportion to the $\mathrm{Cl}^{-}$ concentration in reaction buffers (Fig. 5A). We considered some possibilities to explain how $\mathrm{Cl}^{-}$enhances PTX-induced tubulin polymerization. Roychowdhury et al. $[48,49]$ have reported that $\alpha$-subunit of heterotrimeric G protein stimulates the GTPase activity of tubulin and modulates microtubule dynamics (polymerization/deplolymerization of tubulin). Our previous study also revealed that microtubule polymerization is enhanced by the presence of $\mathrm{Cl}^{-}$via inhibition of intrinsic GTPase activity of $\alpha$-tubulin in vitro [15]. Thus, one possibility is that $\mathrm{Cl}^{-}$would enhance the blocking action of PTX on mitotic transition by suppressing the GTPase activity of tubulin. In this study, the PTX-induced tubulin polymerization with GTP was significantly reduced in $5 \mathrm{mM} \mathrm{Cl}$ buffer (Fig 5A). However, we could not fully rescue the inhibition of tubulin polymerization in $5 \mathrm{mM} \mathrm{Cl}^{-}$buffer even by applying a non-hydrolyzable GTP (GTP $\gamma$ S) instead of GTP (Fig. 5B). Under this condition with GTP $\gamma \mathrm{S}$, the $\mathrm{Cl}^{-}$action on formation of tubulin polymerization is not mediated through suppression of GTPase activity. Therefore, in addition to the $\mathrm{Cl}^{-}$-modulating action on GTPase activity, $\mathrm{Cl}^{-}$would have other potentials for triggering of tubulin polymerization.

Another possibility is that the application of the low $\mathrm{Cl}^{-}$condition would cause diminution of the binding affinity of PTX to tubulin required for tubulin polymerization. Schiff and Horwitz [50] have demonstrated that PTX does not inhibit the binding of GTP or guanosine 5'-diphosphate (GDP) to tubulin. Therefore, we should consider that the effect of $\mathrm{Cl}^{-}$on the intrinsic GTPase activity of tubulin is independent of the effect of $\mathrm{Cl}^{-}$on the PTX binding affinity to tubulin. Several studies have reported that the PTX binds to the luminal site of assembled $\beta$-tubulin in the microtubule. There are three hydrogen bonds and multiple hydrophobic contacts are made between PTX and tubulin [45, 51]. It has also been known that anion modulates protein-protein interaction [52]. Further studies are necessary to clarify the mechanism how $\mathrm{Cl}^{-}$modulates the PTX-tubulin binding. Moreover, in vivo, many proteins are involved in microtubules and microtubule dynamics is regulated by structural MAPs including MAP1 family, tau, MAP2 and MAP4 cross-linking and stabilizing the microtubules, microtubule plus end-tracking proteins (+TIPs) that interact specifically with microtubule plus ends and oncoprotein $18 /$ stathmin inducing microtubule destabilization [45, 51]. Thus, it is necessary to consider a possibility that the change of cytosolic $\mathrm{Cl}^{-}$concentration affects interactions between these proteins and tubulin in living cells.

We should consider a further possibility that $\mathrm{Cl}^{-}$would affect activities and/or expressions of multidrug resistance transporters, such as MDR-1/P-glycoprotein (P-gp), organic anion transporter 2 (OAT2), and organic anion transporting peptide family member (OATP1B3), which are involved in the transport of PTX [53-56]. It is well known that PTX resistance relates with the expression of MDR-1/P-gp known as a member of ATP binding cassette $(A B C)$ transporters showing broad-spectrum multidrug efflux pump ability $[57,58]$. OAT2 and OATP1B3 are multi-specific organic anion transporters that belong to solute carrier (SLC) transporters and are membrane influx transporters that regulate cellular uptake of KARGER 


\section{Cellular Physiology Cell Physiol Biochem 2017;42:68-80 \begin{tabular}{l|l} 
DOI: 10.1159/000477116 & O 2017 The Author(s). Published by S. Karger AG, Basel \\
www.karger.com/cpb
\end{tabular} \\ Tanaka et al.: Effect of Cytosolic $\mathrm{Cl}^{-}$on the Anticancer Activity of Paclitaxel}

a number of endogenous compounds and clinically important drugs $[59,60]$. However, Obuchi et al. [61] have demonstrated that the mRNA expressions of these transporters are not detected in MKN28 cell. Thus, we conclude that the diminution of the blocking action of PTX on mitotic phase progression caused by the reduction of cytosolic $\mathrm{Cl}^{-}$concentration would not be due to the activities of organic transporters related to the multidrug resistance.

In the current study, we specifically focused on the effect of cytosolic $\mathrm{Cl}^{-}$concentration on the microtubule-targeted, antimitotic action of PTX in MKN28 cells. However, microtubules play a fundamental role not only in the mitosis but also in form the cell cytoskeleton. Previous studies have demonstrated that the changes of cytosolic $\mathrm{Cl}^{-}$concentration trigger microtubule remodeling and thereby affects intracellular vesicle trafficking in LLC-PK renal $_{1}$ proximal tubule-like cell [62] and that the application of PTX induces transmembrane $\mathrm{Cl}^{-}$ current and apoptosis in nasopharyngeal carcinoma CNE-2Z cells via upregulation of ClC-3 $\mathrm{Cl}^{-}$channel expression and its accumulation in cell membrane; $\mathrm{ClC}-3 \mathrm{Cl}^{-}$channels are colocalized with membrane microtubules [63]. Consequently, it is possible that PTX would affect tumor cell proliferation not only via the mitotic spindle defects but also by the $\mathrm{Cl}$-dependent remodeling of the microtubule cytoskeleton. The alteration of the microtubule cytoskeleton is highly relevant to cell proliferation and differentiation [64,65]. Microtubule stabilization is regulated by small GTP-binding proteins (small GTPases), which contribute to cell proliferation and differentiation in neural cells $[66,67]$. A previous study has demonstrated that a small GTPase, Ran, participates in cell cycle progression and microtubule organization in mouse oocytes, fertilized eggs and early embryos [68]. Therefore, small GTPases are also promising candidates as cytosolic $\mathrm{Cl}^{-}$targeting molecules. However, more further studies are needed to understand the whole mechanisms by which the cytosolic $\mathrm{Cl}^{-}$and PTX coordinately modulate tumor cell proliferation and apoptosis.

In conclusion, we demonstrated that the cytosolic $\mathrm{Cl}^{-}$influenced PTX-induced cell death and the effect of PTX on mitotic phase progression of MKN28 cells. This study indicates that it would become possible to regulate the effect of PTX by controlling cytosolic $\mathrm{Cl}^{-}$ concentration and consequently cytosolic $\mathrm{Cl}^{-}$would be a novel therapeutic target in clinical anti-cancer therapy.

\section{Acknowledgements}

This work was supported by Grants-in-Aid from Japan Society of the Promotion of Science (JSPS KAKENHI Grant Numbers JP16K08503 to HM, and JP15K15034 to YM), KITKPUM-KPU-KPhU Collaborative Research Grant (2013 and 2015) to YM, Kyoto-Funding for Innovation in Health-related R\&D Fields to YM, and Cell Research Conference to YM.

\section{Disclosure Statement}

The authors declare that they have no conflict of interest.

\section{References}

1 Hawkins T, Mirigian M, Selcuk Yasar M, Ross JL: Mechanics of microtubules. J. Biomech 2010;43:23-30.

-2 Wade RH: On and around microtubules: an overview. Mol Biotechnol 2009;43:177-191.

- J Jordan MA, Wilson L: Microtubules as a target for anticancer drugs. Nat Rev Cancer 2004;4:253-265.

4 McGrogan BT, Gilmartin B, Carney DN, McCann A: Taxanes, microtubules and chemoresistant breast cancer. Biochim Biophys Acta 2008;1785:96-132.

5 Orr GA, Verdier-Pinard P, McDaid H, Horwitz SB: Mechanisms of Taxol resistance related to microtubules. Oncogene 2003;22:7280-7295. 


\section{Cellular Physiology Cell Physiol Biochem 2017;42:68-80 \begin{tabular}{l|l} 
DOI: 10.1159/000477116 & $\begin{array}{l}\text { O 2017 The Author(s). Published by S. Karger AG, Basel } \\
\text { www.karger.com/cpb }\end{array}$
\end{tabular} \\ Tanaka et al.: Effect of Cytosolic $\mathrm{Cl}^{-}$on the Anticancer Activity of Paclitaxel}

6 Busetto S, Trevisan E, Decleva E, Dri P, Menegazzi R: Chloride movements in human neutrophils during phagocytosis: characterization and relationship to granule release. J Immunol 2007;179:4110-4124.

7 Huang W, Liu M, Zhu L, Liu S, Luo H, Ma L, Wang H, Lu R, Sun X, Chen L, Wang L: Functional expression of chloride channels and their roles in the cell cycle and cell proliferation in highly differentiated nasopharyngeal carcinoma cells. Physiol Rep 2014;2

8 Pedersen SF, Hoffmann EK, Novak I: Cell volume regulation in epithelial physiology and cancer. Front Physiol 2013;4:233.

-9 Peretti M, Angelini M, Savalli N, Florio T, Yuspa SH, Mazzanti M: Chloride channels in cancer: Focus on chloride intracellular channel 1 and 4 (CLIC1 AND CLIC4) proteins in tumor development and as novel therapeutic targets. Biochim Biophys Acta 2015;1848:2523-2531.

10 Sardini A, Amey JS, Weylandt KH, Nobles M, Valverde MA, Higgins CF: Cell volume regulation and swellingactivated chloride channels. Biochim Biophys Acta 2003;1618:153-162.

11 Niisato N, Eaton DC, Marunaka Y: Involvement of cytosolic Cl- in osmoregulation of alpha-ENaC gene expression. Am J Physiol Renal Physiol 2004;287:F932-939.

12 Miyazaki H, Shiozaki A, Niisato N, Ohsawa R, Itoi H, Ueda Y, Otsuji E, Yamagishi H, Iwasaki Y, Nakano T, Nakahari T, Marunaka Y: Chloride ions control the G1/S cell-cycle checkpoint by regulating the expression of p21 through a p53-independent pathway in human gastric cancer cells. Biochem Biophys Res Commun 2008;366:506-512.

13 Ohsawa R, Miyazaki H, Niisato N, Shiozaki A, Iwasaki Y, Otsuji E, Marunaka Y: Intracellular chloride regulates cell proliferation through the activation of stress-activated protein kinases in MKN28 human gastric cancer cells. J Cell Physiol 2010;223:764-770.

14 Nakajima K, Miyazaki H, Niisato N, Marunaka Y: Essential role of NKCC1 in NGF-induced neurite outgrowth. Biochem Biophys Res Commun 2007;359:604-610.

15 Nakajima K, Niisato N, Marunaka Y: Enhancement of tubulin polymerization by Cl(-)-induced blockade of intrinsic GTPase. Biochem Biophys Res Commun 2012;425:225-229.

-16 Nogales E, Wolf SG, Downing KH: Structure of the alpha beta tubulin dimer by electron crystallography. Nature 1998;391:199-203.

17 Shedden K, Cooper S: Analysis of cell-cycle-specific gene expression in human cells as determined by microarrays and double-thymidine block synchronization. Proc Natl Acad Sci USA 2002;99:4379-4384.

18 Bostock CJ, Prescott DM, Kirkpatrick JB: An evaluation of the double thymidine block for synchronizing mammalian cells at the G1-S border. Exp Cell Res 1971;68:163-168.

19 Iwamoto E, Ueta N, Matsui Y, Kamijo K, Kuga T, Saito Y, Yamaguchi N, Nakayama Y: ERK Plays a Role in Chromosome Alignment and Participates in M-Phase Progression. J Cell Biochem 2016;117:1340-1351.

20 Nakayama Y, Saito Y, Soeda S, Iwamoto E, Ogawa S, Yamagishi N, Kuga T, Yamaguchi N: Genistein induces cytokinesis failure through RhoA delocalization and anaphase chromosome bridging. J Cell Biochem 2014;115:763-771.

21 Gaskin F, Cantor CR, Shelanski ML: Turbidimetric studies of the in vitro assembly and disassembly of porcine neurotubules. J Mol Biol 1974;89:737-755.

-22 Hamel E, Lin CM: Guanosine 5'-0-(3-thiotriphosphate), a potent nucleotide inhibitor of microtubule assembly. J Biol Chem 1984;259:11060-11069.

23 Hawkins TL, Sept D, Mogessie B, Straube A, Ross JL: Mechanical properties of doubly stabilized microtubule filaments. Biophys J 2013;104:1517-1528.

-24 Hiraoka K, Miyazaki H, Niisato N, Iwasaki Y, Kawauchi A, Miki T, Marunaka Y: Chloride ion modulates cell proliferation of human androgen-independent prostatic cancer cell. Cell Physiol Biochem 2010;25:379388.

25 Jiang B, Hattori N, Liu B, Nakayama Y, Kitagawa K, Inagaki C: Suppression of cell proliferation with induction of p21 by $\mathrm{Cl}^{-}$channel blockers in human leukemic cells. Eur J Pharmacol 2004;488:27-34.

26 Jiang B, Hattori N, Liu B, Nakayama Y, Kitagawa K, Sumita K, Inagaki C: Expression and roles of $\mathrm{Cl}^{-}$channel ClC-5 in cell cycles of myeloid cells. Biochem Biophys Res Commun 2004;317:192-197.

27 Kitagawa M, Niisato N, Shiozaki A, Ohta-Fujimoto M, Hosogi S, Miyazaki H, Ichikawa D, Otsuji E, Marunaka Y: A regulatory role of $\mathrm{K}^{+}-\mathrm{Cl}^{-}$cotransporter in the cell cycle progression of breast cancer MDA-MB-231 cells. Arch Biochem Biophys 2013;539:92-98. 


\section{Cellular Physiology Cell Physiol Biochem 2017;42:68-80 \begin{tabular}{l|l} 
DOI: 10.1159/000477116 & O 2017 The Author(s). Published by S. Karger AG, Basel \\
www.karger.com/cpb
\end{tabular} \\ Tanaka et al.: Effect of Cytosolic $\mathrm{Cl}^{-}$on the Anticancer Activity of Paclitaxel}

28 Maki M, Miyazaki H, Nakajima K, Yamane J, Niisato N, Morihara T, Kubo T, Marunaka Y: Chloride-dependent acceleration of cell cycle via modulation of $\mathrm{Rb}$ and cdc2 in osteoblastic cells. Biochem Biophys Res Commun 2007;361:1038-1043.

29 Shiozaki A, Miyazaki H, Niisato N, Nakahari T, Iwasaki Y, Itoi H, Ueda Y, Yamagishi H, Marunaka Y: Furosemide, a blocker of $\mathrm{Na}^{+}-\mathrm{K}^{+}-2 \mathrm{Cl}^{-}$cotransporter, diminishes proliferation of poorly differentiated human gastric cancer cells by affecting G0/G1 state. J Physiol Sci 2006;56:401-406.

30 Sun H, Niisato N, Inui T, Marunaka Y: Insulin is involved in transcriptional regulation of NKCC and the CFTR Cl- channel through PI3K activation and ERK inactivation in renal epithelial cells. J Physiol Sci 2014;64:433-443.

31 Sun $\mathrm{H}$, Niisato N, Marunaka Y: Quercetin diminishes the cAMP-stimulated $\mathrm{Cl}^{-}$secretion by blocking $\mathrm{Na}^{+}, \mathrm{K}^{+}-$ ATPase in epithelial cells. J Physiol Sci 2014;64:S116.

-32 Sun H, Niisato N, Nishio K, Hamilton KL, Marunaka Y: Distinct action of flavonoids, myricetin and quercetin, on epithelial $\mathrm{Cl}^{-}$secretion: useful tools as regulators of $\mathrm{Cl}^{-}$secretion. Biomed Res Int 2014;2014:902735.

-33 Marunaka Y, Niisato N, Miyazaki H, Nakjima K, Taruno A, Sun H, Marunaka R, Okui M, Yamamoto T, Kanamura N, Kogiso H, Ikeuchi M, Kashio M, Hosogi T, Nakahari T: Quercetin is a useful medicinal compound showing various actions including control of blood pressure, neurite elongation and epithelial ion transport. Curr Med Chem 2016;(in press)

34 Marunaka Y, Niisato N, Taruno A, Ohta M, Miyazaki H, Hosogi S, Nakajima K, Kusuzaki K, Ashihara E, Nishio K, Iwasaki Y, Nakahari T, Kubota T: Regulation of epithelial sodium transport via epithelial $\mathrm{Na}^{+}$channel. J Biomed Biotechnol 2011;2011:978196.

-35 Menegazzi R, Busetto S, Decleva E, Cramer R, Dri P, Patriarca P: Triggering of chloride ion efflux from human neutrophils as a novel function of leukocyte beta 2 integrins: relationship with spreading and activation of the respiratory burst. J Immunol 1999;162:423-434.

-36 Menegazzi R, Busetto S, Dri P, Cramer R, Patriarca P: Chloride ion efflux regulates adherence, spreading, and respiratory burst of neutrophils stimulated by tumor necrosis factor-alpha (TNF) on biologic surfaces. J Cell Biol 1996;135:511-522.

37 Miyazaki H, Marunaka Y: The molecular mechanism of intracellular $\mathrm{Cl}^{-}$function in gastric cancer invasion and metastasis by regulating expression of cell adhesion molecules. J Physiol Sci 2015;65:S72.

38 Nagao H, Nakajima K, Niisato N, Hirota R, Bando H, Sakaguchi H, Hisa Y, Marunaka Y: $\mathrm{K}^{+}$- $\mathrm{Cl}^{-}$cotransporter 1 (KCC1) negatively regulates NGF-induced neurite outgrowth in PC12 cells. Cell Physiol Biochem 2012;30:538-551.

-39 Nakajima K, Niisato N, Marunaka Y: Genistein enhances the NGF-induced neurite outgrowth. Biomed Res 2011;32:351-356.

40 Nakajima K, Niisato N, Marunaka Y: Quercetin stimulates NGF-induced neurite outgrowth in PC12 cells via activation of $\mathrm{Na}^{+}-\mathrm{K}^{+}-2 \mathrm{Cl}^{-}$cotransporter. Cell Physiol Biochem 2011;28:147-156.

41 Liu C, Schilling JK, Ravindra R, Bane S, Kingston DG: Syntheses and bioactivities of macrocyclic paclitaxel bis-lactones. Bioorg Med Chem 2004;12:6147-6161.

42 Sampath D, Greenberger LM, Beyer C, Hari M, Liu H, Baxter M, Yang S, Rios C, Discafani C: Preclinical pharmacologic evaluation of MST-997, an orally active taxane with superior in vitro and in vivo efficacy in paclitaxel- and docetaxel-resistant tumor models. Clin Cancer Res 2006;12:3459-3469.

43 Sharma S, Ganesh T, Kingston DG, Bane S: Promotion of tubulin assembly by poorly soluble taxol analogs. Anal Biochem 2007;360:56-62.

44 Jordan MA, Toso RJ, Thrower D, Wilson L: Mechanism of mitotic block and inhibition of cell proliferation by taxol at low concentrations. Proc Natl Acad Sci USA 1993;90:9552-9556.

45 Honore S, Pasquier E, Braguer D: Understanding microtubule dynamics for improved cancer therapy. Cell Mol Life Sci 2005;62:3039-3056.

46 Schiff PB, Fant J, Horwitz SB: Promotion of microtubule assembly in vitro by taxol. Nature 1979;277:665667.

47 Schiff PB, Horwitz SB: Taxol stabilizes microtubules in mouse fibroblast cells. Proc Natl Acad Sci USA 1980;77:1561-1565.

48 Roychowdhury S, Panda D, Wilson L, Rasenick MM: G protein alpha subunits activate tubulin GTPase and modulate microtubule polymerization dynamics. J Biol Chem 1999;274:13485-13490.

49 Roychowdhury S, Rasenick MM: Submembraneous microtubule cytoskeleton: regulation of microtubule assembly by heterotrimeric Gproteins. FEBS J 2008;275:4654-4663. 


\section{Cellular Physiology Cell Physiol Biochem 2017;42:68-80 \begin{tabular}{l|l} 
DOI: 10.1159/000477116 & O 2017 The Author(s). Published by S. Karger AG, Basel \\
www.karger.com/cpb
\end{tabular} \\ Tanaka et al.: Effect of Cytosolic $\mathrm{Cl}^{-}$on the Anticancer Activity of Paclitaxel}

50 Schiff PB, Horwitz SB: Taxol assembles tubulin in the absence of exogenous guanosine 5'-triphosphate or microtubule-associated proteins. Biochemistry 1981;20:3247-3252.

51 Field JJ, Diaz JF, Miller JH: The binding sites of microtubule-stabilizing agents. Chem Biol 2013;20:301-315.

52 Gokarn YR, Fesinmeyer RM, Saluja A, Cao S, Dankberg J, Goetze A, Remmele RL, Jr., Narhi LO, Brems DN: Ion-specific modulation of protein interactions: anion-induced, reversible oligomerization of a fusion protein. Protein Sci 2009;18:169-179.

53 Collett A, Tanianis-Hughes J, Hallifax D, Warhurst G: Predicting P-glycoprotein effects on oral absorption: correlation of transport in Caco-2 with drug pharmacokinetics in wild-type and mdr1a(-/-) mice in vivo. Pharm Res 2004;21:819-826.

54 Kimura Y, Kioka N, Kato H, Matsuo M, Ueda K: Modulation of drug-stimulated ATPase activity of human MDR1/P-glycoprotein by cholesterol. Biochem J 2007;401:597-605.

55 Kobayashi Y, Ohshiro N, Sakai R, Ohbayashi M, Kohyama N, Yamamoto T: Transport mechanism and substrate specificity of human organic anion transporter 2 (hOat2 [SLC22A7]). J Pharm Pharmacol 2005;57:573-578.

56 Smith NF, Acharya MR, Desai N, Figg WD, Sparreboom A: Identification of OATP1B3 as a high-affinity hepatocellular transporter of paclitaxel. Cancer Biol Ther 2005;4:815-818.

57 Gottesman MM: Mechanisms of cancer drug resistance. Annu Rev Med 2002;53:615-627.

58 Gottesman MM, Fojo T, Bates SE: Multidrug resistance in cancer: role of ATP-dependent transporters. Nat Rev Cancer 2002;2:48-58.

59 Kalliokoski A, Niemi M: Impact of OATP transporters on pharmacokinetics. Br J Pharmacol 2009;158:693705.

60 Niemi M: Role of OATP transporters in the disposition of drugs. Pharmacogenomics 2007;8:787-802.

61 Obuchi W, Ohtsuki S, Uchida Y, Ohmine K, Yamori T, Terasaki T: Identification of transporters associated with Etoposide sensitivity of stomach cancer cell lines and methotrexate sensitivity of breast cancer cell lines by quantitative targeted absolute proteomics. Mol Pharmacol 2013;83:490-500.

62 Nunes P, Roth I, Meda P, Feraille E, Brown D, Hasler U: Ionic imbalance, in addition to molecular crowding, abates cytoskeletal dynamics and vesicle motility during hypertonic stress. Proc Natl Acad Sci USA 2015;112:E3104-3113.

63 Zhang H, Li H, Yang L, Deng Z, Luo H, Ye D, Bai Z, Zhu L, Ye W, Wang L, Chen L: The ClC-3 chloride channel associated with microtubules is a target of paclitaxel in its induced-apoptosis. Sci Rep 2013;3:2615.

64 Corydon TJ, Mann V, Slumstrup L, Kopp S, Sahana J, Askou AL, Magnusson NE, Echegoyen D, Bek T, Sundaresan A, Riwaldt S, Bauer J, Infanger M, Grimm D: Reduced Expression of Cytoskeletal and Extracellular Matrix Genes in Human Adult Retinal Pigment Epithelium Cells Exposed to Simulated Microgravity. Cell Physiol Biochem 2016;40:1-17.

65 Huang H, Liu L, Li B, Zhao PP, Xu CM, Zhu YZ, Zhou CH, Wu YQ: Ketamine interferes with the proliferation and differentiation of neural stem cells in the subventricular zone of neonatal rats. Cell Physiol Biochem 2015;35:315-325.

66 Chen S, Luo M, Zhao Y, Zhang Y, He M, Cai W, Liu A: Fasudil Stimulates Neurite Outgrowth and Promotes Differentiation in C17.2 Neural Stem Cells by Modulating Notch Signalling but not Autophagy. Cell Physiol Biochem 2015;36:531-541.

67 Lu XC, Zheng JY, Tang LJ, Huang BS, Li K, Tao Y, Yu W, Zhu RL, Li S, Li LX: MiR-133b Promotes neurite outgrowth by targeting RhoA expression. Cell Physiol Biochem 2015;35:246-258.

68 Cao YK, Zhong ZS, Chen DY, Zhang GX, Schatten H, Sun QY: Cell cycle-dependent localization and possible roles of the small GTPase Ran in mouse oocyte maturation, fertilization and early cleavage. Reproduction 2005;130:431-440. 